О. А. Стишов

\title{
СЕМАНТИЧНІ НЕОЛОГІЗМИ В ДИСКУРСІ УКРАЇНСЬКОМОВНИХ МАС-МЕДІА ПОЧАТКУ ХХІ СТОЛІТТЯ
}

Стишов О. А. Семантичні неологізми в дискурсі українськомовних мас-медіа початку XXI століття.

У статті проведено аналіз деяких тенденцій у семантичній деривації, що намітилися й активно діють як у літературній, так і в загальнонародній українській мові початку XXI століття на матеріалі дискурсу українсьмовних ЗМІ. Схарактеризовано семантичні неологізми, що постали завдяки розширенню семантичної структури питомих і запозичених слів переважно на основі метафори і метонімії. метонімія.

Ключові слова: семантика, ЗМІ, дискурс, чинники, неологізм, метафора,

Стишов А. А. Семантические неологизмы в дискурсе украиноязычных массмедиа начала XXI века.

(c) О. А. Стишов, 2015. $-364-$ 
В статье анализируются некоторые тенденции в семантической деривации, наметившиеся и активно действующие как в литературном, так и в общенародном украинском языке начала XXI века на материале дискурса украиноязычных СМИ. Охарактеризированы семантические неологизмы, возникшие вследствие расширения семантической структуры исконных и заимствованных слов преимущественно на основе метафоры и метонимии.

Ключевые слова: семантика, СМИ, дискурс, факторы, неологизм, метафора, метонимия.

Styshov O. A. Semantic neologisms in the discourse of Ukrainian media at the beginning of the XXI century.

The article examines some of the trends in the semantic derivation that actively operate in the literary and vulgar Ukrainian language at the beginning of the XXI century on discourse material of Ukrainian media. The semantic neologisms which are arisen from expansion of the semantic structure of native and loan words mainly on the basis of metaphor and metonymy are characterized.

Key words: semantics, media discourse, factors, neologism, metaphor, metonymy.

Нині світова спільнота вступила в нову стадію еволюції інформаційного суспільства. Це істотно впливає на сучасні живі мови як відкриті і динамічні системи. Вони під впливом екстра- й інтралінгвальних чинників постійно перебувають у розвитку, зазнаючи як кількісних, так i якісних змін. Українська мова нинішньої доби також розвивається у названому руслі, і серед усіх іiї рівнів найбільшою динамікою відзначається лексико-семантичний. Тому проблеми ономасіології, особливо заповнення мовних лакун, виникнення i функціонування нових слів, були й залишаються в україністиці досить актуальними як у теоретичному, так і в практичному плані. Поряд із всебічним дослідженням лексичних i словотворчих неологізмів, важливого значення сьогодні набуває скрупульозне вивчення семантичних інновацій. У цьому аспекті слушною видається думка Ж. Колоїз про те, що процеси семантичної деривації виступають потужним фактором, що забезпечує інноваційні зміни в мові, через це теорію семантичної деривації варто не заперечувати, а розвивати $[1$, c. 161]. Адже відомо, що семантична деривація - це досить складний i багатогранний номінативний процес у продукуванні нових слів i ïx значень, що спричинює перебудову їх семантичної структури і впливає на всю лексико-семантичну систему мови загалом.

Семантична деривація як один із важливих способів збагачення й істотного поповнення лексичного складу мов, а також семантичні трансформації слів уже були предметом ряду праць таких відомих зарубіжних і українських лінгвістів, як: R. Bartsch, M. Johnson, G. Lakoff, 
F. Daneš, D. Cruse, F. Palmer, В. Виноградов, Д. Шмельов, О. Кубрякова, В. Телія, О. Срмакова, О. Потебня, Л. Булаховський, В. Русанівський, Л. Лисиченко, О. Тараненко, Ю. Карпенко, М. Полюжин та ін. Не зникає, а навпаки, постійно зростає інтерес до цих питань і в україністиці останніх десятиліть, що й засвідчено в низці досліджень М. Кочергана, О.Семенюка, Л. Струганець, М. Навальної, І. Самойлової, Т. Бевз, Д. Мазурик, Д. Деркача, Д. Сизонова, О. Ляхової і багатьох ін.). Однак, на нашу думку, ця проблема в нашій мові на початку XXI століття потребує більш виваженого і грунтовнішого розгляду, комплексних студій, оскільки кількість неосемантизмів неухильно зростає та урізноманітнюється, заповнюючи номінативні лакуни, що постійно виникають, збагачуючи емоційноекспресивні засоби загальнонародної української мови. Тому вона була i залишається досить актуальною. До того ж семантичні неологізми чекають належного витлумачення і лексикографічного опрацювання.

Мета статті - ввести до наукового обігу нові цікаві факти, явища, одиниці, переважно не зафіксовані українськими лексиконами, провести аналіз деяких тенденцій у семантичній деривації, що намітилися й активно діють як у літературній, так і в загальнонародній українській мові початку нового тисячоліття.

Матеріалом для дослідження слугували семантичні неологізми (понад 150 слів), зафіксовані нами здебільшого у сучасній публіцистиці газетах, журналах, програмах і передачах радіо й телебачення, а також Інтернет-виданнях протягом $2000-2015$ років.

Зібраний фактичний матеріал та його аналіз дають підстави твердити, що в корпусі семантичних інновацій зазначеного часового зрізу істотно домінують одиниці, у яких відбулося зростання семантичного обсягу переважно за рахунок розширення сфери їх уживання, тобто збільшення числа контекстів, де це слово може використовуватися. Генералізацію, услід за О. Ляховою, трактуємо не як просте збільшення (додавання) кількості значень (лексико-семантичних варіантів, сем) полісеманта, а як зміни, пов'язані 3 особливими семантичними трансформаціями слова, які спричиняють знецінення конкретної семантичної ознаки, збільшення кола позначуваних словом понять, збільшення обсягу семантики слова до появи надзвичайно широкого значення [2, с. 57]. Засвідчено перевагу цього процесу під час комунікації в словах на позначення загальних назв. Це можуть бути як питомі лексичні одиниці, так і іншомовні слова.

Серед питомих лексем, у яких відбулося розширення семантичного обсягу переважають іменники. Так, наприклад, відоме слово хом'як, крім значень, зафіксованих у Словнику української мови в 11-ти томах ○ О. А. Стишов, 2015. 
(1. «польовий гризун з товстим, неповоротким тілом і добре розвиненими защічними мішками, шкідник польових і городніх культур. 2. перен., розм. неповоротка, незграбна, нерозторопна людина» [СУМ-11, ХI, с. 124]), останнім часом набуло нової семантики - «особа, яка надійно сховала свої фінанси»: Сподіваючись на політичну ци економічну стабільність та визначеність, багато «хом'яків», які надійно сховали свої фінанси в період розгортання першої хвилі економічної кризи, вийняли заощадження зі своїх засіків $і$ вийшли з ними на ринок нерухомості («Дзеркало тижня», 14.05. 2010). Ще однією ілюстрацією може слугувати лексична одиниця дояр («робітник, який доїть і доглядає корів» [СУМ-11, II, с. 403]), яка функціонує у сучасній українській мові також з інноваційним значенням «здирник, драпіжник». Пор.: Відомий російський письменник-гуморист М. Задорнов абревіатуру ДАї «переклав» на російський алфавіт як ДАЙ $i$, відповідно, даїшників назвав «ооярами». Задорнов став популяризатором самої лексеми дояр (здирник). Суспільство змушено констатувати: «Ми стали країною доярів». bratstvo.vn.uа〉. Також загальновживане слово тушка («зменш. до туша (у 1 знач.); тіло убитої тварини, дичини і т. ін. невеликого розміру» [СУМ-11, ХI, с. 124]) в політичному лексиконі набуло ознак експресивної назви, розширивши свій семантичний обсяг i вживаючись переважно у множині, - «безпринципні депутати Верховної Ради України, які переходять із фракції у фракцію та голосують 3 урахуванням особистої матеріальної вигоди або під тиском»: Навіть разом із комуністами $i$ «тушками», Партії регіонів не вдається створити конституційну більшість у новому парламенті. tyzhden.ua/. Цікаво, що навіть окремі застарілі слова в дискурсі сучасних ЗМІ здатні набувати нових значень. Це стосується лексичної одиниці царедворець, яка, крім відомої семантики, зафіксованої в словнику (книжн., заст. «особа, що займає посаду при царському дворі, царський вельможа; придворний» [СУМ-11, ХІ, с. 181]), нині функціонує і як «самодержець, самовладець; диктатор», пор.: Після маразму президента РФ Путіна, виголошеного на виправдання військової агресії проти суверенної України, - світ дізнався, щзо цей новітній кремлівський царедворець не на стільки розумний, як то здавалось протягом попереднього часу. nas.vinnica.ua/. Характерно, що подані вище приклади слугують переконливим доказом посилення антропоцентризму в українській мові початку XXI століття.

Розширення семантичного обсягу слова спостерігаємо і в іменниках на позначення неістот. У здавна відомому власне українському слові рушник (1. «довгастий шматок тканини (бавовняної, лляної, полотняної і т. ін.) для витирання обличчя, тіла, посуду тощо. 2. шматок декоративної 
тканини 3 вишиваним або тканим орнаментом; традиційно використовується для оздоблення житла, в українських народних обрядах i т. ін.» [СУМ-11, VIII, с. 919]) виникло інноваційне значення «виборчий бюлетень із прізвищами, іменами, по батькові кандидатів у депутати різних рад», що й засвідчено в текстах мас-медійного дискурсу: $\epsilon$ другий варіант, коли виборецьь отримує десяток невеликих «рушників»-бюлетенів, у які внесені прізвища, імена, по батькові $i$ коротка біографічна довідка кандидатів від партї, які безпосередньо закріплені за певним регіоном (осіб 10-15). Голосування ж проходить за такою схемою: крім галочки за конкретну партію або блок виборецуь розташовує прізвища за ступенем значущуості («День», 16.04. 2009). Пробудження національної свідомості й відродження багатьох народних культурних і духовних надбань під час i після Революції гідності в Україні сприяло появі нової семантики в лексемі вишиванка (розм. «вишита сорочка» [СУМ-11, I, с. 540]) - «смуга 3 національним українським орнаментом, м'який магніт, наклейка 3 гербом України тощо, що прикріпляється на будь-яку частину кузова, найчастіше на капот, кришку і задній бампер автомобіля»: Одягніть справжню вишиванку на власний автомобіль, перетворіть його на яскравий $i$ неповторний зразок дизайну. boschservice.lviv.ua〉.

Демократизація життя, відсутність цензури й автоцензури сприяли бурхливому розвиткові субстандартної лексики (нелітературні розмовні слова, діалектизми, жаргонізми, арготизми) в українській мові кінця ХХ початку XXI ст., що висуває перед лінгвістами проблему вивчення семантичних змін у ній. Такі нові значення поки що не зафіксовані в лексикографічних працях, хоча практично відомі багатьом мовцям й активно функціонують у розмовному, почасти публіцистичному та художньому дискурсах. Так, слово гойдалка («споруда, на якій гойдаються для розваги діти й молодь» [СУМ-11, II, с. 105]) нині набуло двох колоквіальних значень - 1) «поперемінні атаки в бік воріт, кільця і т. ін. то однієї, то іншої команди» (пор.: А на полі в нас знову гойдалки від обох команд. М'яч опинясться то біля однієї, то біля другої итрафної. fask.com.ua/; Гойдалки тривали протягом усього матчу й, в решті, гра перейшла у екстратайм. cherkassysport.com/) i 2) «коливання курсу певної грошової одиниці то в бік зростання, то в бік падіння» (пор.: Експерт: в Україні скоро почнуться валютні «гойдалки» (заголовок) businessua.com/; Ниніині валютні гойдалки в Україні повторюють ситуацію 2009 року часів Віктора Ющенка. espreso.tv/news/). Відоме питоме слово кріт («невеликий комахоїдний ссавець, що живе під землею; цінний своїм хутром» [CУМ-11, IV, с. 358]) у спортивному жаргоні розширило свою семантику i, вживаючись переважно у множині, означає

() О. А. Стишов, 2015. 
«спортсмени або вболівальники-фанатики футбольного клубу «Шахтар». Про це переконливо засвідчують такі контексти: Відбійні молотки на емблемі, помаранчево-чорна символіка, що уособлює колір касок і спецодягу, і неофіиійне прізвисько - «кроти». zaxid.net/news/; Проте навколофутбольна ворожнеча не завжди заважає спільним справам. "Севастопольиі, наприклад, приїздил до нас на марш УПА та на інші акиії, - розповідає Ед. - Донецькі «кроти» були на мариі за тверезість 2009 року. tyzhden.ua/.

У добу глобалізації, коли контакти і взаємодія між представниками різних етносів і їх мовами зростає і коли анлійська мова стала практично світовою, активізується розширення значень як у давніх, так і в нових запозиченнях. Правда, зауважимо, що лінгвістам варто чітко розрізняти, чи зміни в семантичній структурі запозичення відбулися ще мові-джерелі, чи в мові-посереднику, чи вже в мові, яка приймає? Так, однією з ілюстрацій може слугувати відоме слово борт. У ньому, крім значень, зафіксованих найбільшими українськими тлумачними словниками (див. [СУМ-11, I, c. 221]), на початку XXI століття з англійської мови в українську ввійшло ще одне (четверте), яке вже зафіксоване в Словнику української мови в 20ти томах як розмовне, - «літак» (див. [СУМ-20, I, с. 607]): Сьогодні у вінницькому військово- медичному клінічному центрі приймали новий борт з пораненими бійцями. www.0432.ua/.

Фактичний матеріал засвідчує, що серед запозичень, які зазнали розширення семантики, в українській мові початку XXI століття переважають давні входження 3 різних мов. Прикладом слугує слово карусель, яке, крім відомих значень (1. «споруда із сидіннями у вигляді коней, човнів і т. ін., що швидко обертається навколо вертикальної осі; встановлюється на ярмарках, у парках для розваги. 2. техн. те саме, що Карусельний верстат (див. карусельний)» [СУМ-11, IV, с. 113]), нині набуло ще й інноваційної семантики «метод фальсифікації виборів, коли створюються умови для багаторазового голосування за певного кандидата». Напр. у контекстах: У Чернігові на одній з дільниць намагалися організувати виборчу «карусель». tsn.ua/; Фальсифікації на «референдумі» в Криму: мертві та російські душі, каруселі ц̆ примусовий вибір. tyzhden.ua/. Екстралінгвальні чинники зумовили відродження, актуалізацію вживання i розширення семантичного обсягу слова волонтер. Так, у Словнику української мови в 11-ти томах воно зафіксоване як застаріле лише з одним значенням - «той, хто став на військову службу за власним бажанням; доброволець» [СУМ-11, I, с. 730]). У зв'язку з відомими подіями в Україні, названа лексична одиниця набула нового значення i нового відтінку значення, що й зафіксовано в Словнику української мови в 20-ти томах: 
«2. той, хто добровільно бере участь у якійсь соціально важливій справі (перев. новій, важкій чи небезпечній для життя); доброволець (у 2 знач.)». Апробацію запропонованого нового фізіотерапевтичного методу проведено на волонтерах, які хворіють на остеохондроз хребта (з наук. літ.); Синтетичні мийні засоби, щуо не викликають подразнення шкіри і не мають сенсибілізувальної діі на організм, допускаються до другого етапу досліджень, до якого залучаються тільки волонтери (з наук. літ.); // «особа, яка за власним бажанням допомагає іншим; помічник (у 1 знач.)». Основна причина звернення до роботи волонтера для більшості - необхідність у спілкуванні, соиіальній активності, потреба відчувати себе корисним для інших (з наук. літ.); Дехто з відвідувачів навіть зголосився стати волонтером у клініці (з газ.) [СУМ-20, III, с. 266]. Цікаво, що іншомовні слова, які порівняно недавно з'явилися в українській мові, також можуть набувати нової семантики. Проілюструємо це на новозапозиченні 3 англійської мови секонд-хенд (від англ. second - другий і hand - рука; second-hand - який був у використанні (переважно одяг). Окрім зафіксованих значень (1. «магазин, що торгує ношеним одягом і взуттям. // збірн. ношені речі. 2. ношений, такий, що був у користуванні, куплений у комісійному магазині» [8, с. 1033] ), в останні роки це слово в суспільно-політичному дискурсі поступово набуває інноваційної семантики - «застарілі, консервативні політичні методи і політики, які користуються ними; а також віджилі політичні ідеї і технології», напр.: Список опозиції - це політичний секонд-хенд (заголовок) glavcom.uа); Опозиціонер [Андрій Парубій] назвав Азарова «політичним секонд-хендом» (заголовок) 24tv.ua).

Крім значної кількості іменників, розширення семантичного обсягу слова засвідчено також і в ряді дієслів (3 прогнозами аналітиків, євро помітно «просяде» (Телеканал «24», 14.09. 2011) - «девальвує, знеціниться»; Чернігівські пенсіонерки підірвали ҮоиТиве піснею про «лісапед» (ВІДЕО) tsn.ua/ - «надзвичайно вразили, приголомшили») та прикметників (Німецька енергетика нині орієнтована на «зелені» технологіі (Телеканал «24», 29.10. 2011) - «екологічно чисті»; Державтоінспекція в рамках боротьби 3 «сірим» імпортом автомобілів, відмовляється реєструвати машини, ввезені до України за пільговими схемами. У 2007 рочуі бюджет вже втратив 2,8 млрд грн через «сірий» імпорт авто. www.newsru.ua/ - «незаконний»).

Зібраний нами фактичний матеріал i спостереження інших дослідників переконливо доводять, що найпродуктивнішим видом лексикосемантичної деривації у дискурсі ЗМI початку XXI століття $є$ метафора. Високу інтенсивність такого словотворення можна пояснити універсальністю метафори як традиційного способу вторинної номінації, ○ О. А. Стишов, 2015. 
побудованому на перенесенні з одних об'єктів, дій чи ознак дійсності на інші за певною подібністю, на прихованому порівнянні, образних асоціаціях тощо. Це найпродуктивніший креативний засіб збагачення мови, вияв мовної економії, семіотична закономірність [3, с. 326]. Метафора - когнітивний процес, спосіб світобачення певного етносу чи індивідуума.

У мові сучасних мас-медіа засвідчено значну кількість текстів із використанням різнопланових метафор, які розширюють семантичний обсяг слів. Чимало метафор у дискурсі ЗМІ початку XXI століття виникає на основі загальнонародної лексики: Він [футболіст Юліан Дракслер] став значно технічнішим $i$ почав читати гру (Телеканал «Футбол-2», 28.08.2011) - «розуміти, усвідомлювати, правильно сприймати що-небудь»; Упродовж семи років життя на франківській сцені «Солодка Даруся» тримається у першій топ-трійці вистав, які приносять найбільший дохід театру. «Це такий хіт-лайнер нашого прокату, - зазначає Ростислав Держипільський. - Для мене як режисера це, з одного боку, джек-пот, $з$ іншого, я розумію, щуо в иүю виставу вкладено багато досвіду, любові до землі украӥнської й до театру». www.blitz.if.ua/ - «найбільша перемога, досягнення, успіх». Характерна риса публіцистики початку XXI століття метафоризація термінів різних галузей людської діяльності (від військових до кулінарних). Передусім це стосується спеціальної лексики: 1) військової справи: На таких танках їздть тільки братва й народні депутати (радіо «Промінь», 18.04.2014) - «потужний, надзвичайно дорогий і престижний автомобіль»; У всьому світі знімають без бюджетні фільми. I вони «вистрілюють» (радіо «Промінь», 28.11.2012); Найвищою формою безпосередньої демократії є референдум. Нещодавно ухвалено закон «Про всеукраӥнський референдум». Як думаєте, коли він «вистрілить»? clipnews.info/; «Динамо» виграло матч, який міг $i$ не відбутися: вистрілив [футболіст] Безус (заголовок) uafootballukr.segodnya.ua/ - «мати успіх, популярність, значний суспільний резонанс; досягти чого-небудь»; 2) медицини: Вони [сепаратисти на сході Украӥни] «інфіковані» україноненависництвом (радіо «Промінь», 10.08.2014) - «просякнуті, фанатично схильні до чого-небудь»; Більш детальний «розтин» ичих економічних термінів ми будемо робити в ході передачі (радіо «Промінь», 16.12.2011) - «розбір, аналіз»; 3) біології: Кандидат від партії Ляшка поширював клон газети конкурента з «чорним піаром» ... lad.vn.ua/; Ще однією ијікавою категорією кандидатів у депутати $\epsilon$ політичні клони, або двійники-однофамільијі, відомих політиків («Поступ», 22.02.2002) - « хто- або що-небудь однакове або дуже схоже між собою»; 4) мистецтва: ... «кіборги» з донецького аеропорту 
назвали борщ теплофізиків найсмачнішим з усього того, щуо ӥм доводилося їсти на війні («Урядовий кур'єр», 16.01.2015) - «надзвичайно мужні і витривалі військовики, які б'ються 3 ворогами як роботи, на межі неможливого, оскільки жива людина так битися не може»; 5) виробничотехнічної: Судову систему [в Україні] треба «ремонтувать» (радіо «Промінь», 28.10.2013) - «усувати недоліки, помилки, невідповідності»; 5) кулінарії: Сьогодні в нашому «меню» цікаві розмови щзодо украӥнського газу (радіо «Промінь», 05.05.2014) - «перелік тем для обговорення» та ін.

У дискурсі ЗМІ початку XXI століття трохи рідше засвідчено творення нових значень слів шляхом ще одного важливого креативного мовного засобу - метонімії. Її підгрунтям слугує наявність зв'язків між категоріями й поняттями у мисленнєвій діяльності людини. Виникнення метонімій досліджуваного періоду зумовлене переважно екстралінгвальними чинниками. Так, саме під час Революиї гідності (Свромайдану), тобто національно-патріотичних, протестних акцій в Україні (2013-2014рр.), передусім, проти корупції, соціальної нерівності, свавілля правоохоронних органів та сил спецпризначення, а також на підтримку європейського вектора зовнішньої політики України, які завершилися зміною влади, виникло слово майдан із новим значенням «акція протесту та сукупність людей, які беруть участь у ній; територія свободи (у місті Києві та багатьох населених пунктах України і зарубіжжя)»: Доки йшлося тільки про євроінтеграцію, Майдан хотів $i$, в принцииі, міг обійтися без політиків. Але коли постало питання про заміну людей при владі, або, тим більше, про зміну системи влади, то без політиків уже обійтися не можслио. political-studies.com/; ... завдяки Майдану $i$, на жаль, завдяки війні на Сході зараз є украӥнська політична нація, яка є трошки іншою, ніж три роки тому. hromadskeradio.org/. Ще одним прикладом впливу соціально-політичних подій - війни на сході України - на мову є слово ватник. На основі відомого значення «верхній одяг, стьобаний на ваті» [СУМ-20, II, с. 70] у названій лексемі в останні роки на основі метонімічного перенесення розвинулася нова семантика «малоосвічений, люмпенізований та здебільшого проросійсько налаштований громадянин, чия соціально-політична позиція суттєво спотворена внаслідок перманентного впливу російської пропаганди». Пор.: Як бик кидається на червоне, так ватник на жовто-блакитне ...(Телеканал «24», 07.07.2015); Спалений украӥнський прапор $i$ залиті ненавистю спорожнілі очі «ватників» ще гикнуться диктатору наших часів («День», 30.04.2015); Переконувати «ватників» у тому, щуо вони неправі - безнадійна справа. Якщо людина не здатна слухати, то діалогу не вийде («День», 20.11.2014).

(ㅇ О. А. Стишов, 2015. 
У досліджувану добу розширення семантичного обсягу слова на основі метонімії відбувається і в іменниках на позначення істот, зокрема у пропріальних одиницях. Передусім це стосується відомих осіб. Переконливою ілюстрацією слугує слово Шумахер - «усесвітньо відомий автогонщик». Нині в розмовному дискурсі, а також і в мові мас-медіа активно побутує загальна назва шумахер із інноваційним значенням «водій, який зловживає швидкістю; той, хто любить швидку їзду», хача словники іiі поки що не фіксують. Напр.: Паркан пані Лідї вже не вперше зносять місиеві «шумахери». Вулиця, на якій проживає жінка, досить вузька $i$ з різкими поворотами. Водії тут часто розганяються та на швидкості не можуть розминутися, а в результаті вилітають з дороги («Буковинська правда», 14.09.2015). Екстралінгвальні чинники (Революція гідності) сприяли також появі ще одного семантичного неологізму - тітушка, який у дискурсі 3МI функціонує переважно у множині (тітушки) і нині вже закріпився як суспільно-політичний термін зі значенням «наймані молодики спортивної статури, які використовувалися владою для придушення протестних акцій населення, побиття журналістів, впливу на процес голосування на виборах тощо». Пор. у контекстах: Слідство має докази того, щчо зброя, яка була у «тімушок» під час Майдану, значилася на складах МВС («День», 02.02.2015); Міліція перевіряє інформацію про наплив тітушок до Києва (заголовок статті) («Дзеркало тижня», 05.05.2014); Тімушки, які діяли під час Револючії гідності, фактично були прообразом бойовиків, які зараз діють на Донбасі. www.radiosvoboda.org/. Слово стало узагальнювальною назвою, походить від прізвища спортсмена 3 Білої Церкви Вадима Тітушка, який 18 травня в Києві напав на журналістів Ольгу Сніцарчук та Влада Соделя. Також із новим узагальнювальним значенням здебільшого в політичному лексиконі побутує одиниця бен ладени «міжнародні терористи», утворене від пропріальної назви Оса́ма бен Ла́ден - колишній лідер міжнародної ісламської терористичної організації «Аль-Каїда».

Наведені вище матеріали засвідчують, що в сучасних друкованих та електронних мас-медіа журналісти й учасники комунікації вдаються переважно до створення емоційно-експресиних, образних метафор i метонімій із метою подати інформацію не сухо, трафаретно, а оригінально, досягти ефективності друкованого слова, його дієвості, щоб воно проникло в серця респондентів.

Отже, фактичний матеріал і проведена студія переконливо засвідчує, що процеси семантичної деривації в дискурсі українськомовних ЗМІ початку XXI століття діють досить активно. Цьому сприяли чинники переважно 
позамовного характеру, хоч вони були тісно пов'язані з інтралінгвальними. Особливо продуктивно відбуваються процеси розширення семантичного обсягу як у питомих, так запозичених словах, зокрема не лише літературних, а й субстандартних, переважно на основі метафори і метонімії.

Перспективним убачаємо подальше студіювання різноманітних процесів семантична деривації у зіставних дослідженнях як близько-, так далеко споріднених мов.

\section{Література}

1. Колоїз Ж. В. Українська оказіональна деривація : [монографія] / Ж. В. Колоїз. К. : Акцент, 2007. - $311 \mathrm{c.}$

2. Ляхова О. В. Динамічні процеси в лексико-семантичній системі сучасної української мови: розширення значень похідного слова : дис... канд. філол. наук / О. В. Ляхова. - Х., 2012. -200 с.

3. Селіванова О. Сучасна лінгвістика : термінологічна енциклопедія / О. Селіванова. - Полтава : Довкілля-К, 2006. - 716 с.

4. Словник української мови : в 11-и тт. - К. : Наукова думка, 1970-1980. - Т. I, II, IV, VIII, XI.

5. Словник української мови : у 20-и тт. - К. : Наукова думка, 2010. - Т. І. - 912 с.

6. Словник української мови : у 20-и тт. - К. : Наукова думка, 2012. - Том II. - 976 с.

7. Словник української мови : у 20-и тт. - К. : Кий, 2012. - Том III. -1120 с.

8. Словник української мови. - К. : ВЦ «Просвіта», 2012. - 1320 с.

Стаття надійшла до редакиї 21.08.2015 p. 